\title{
Madness and the Alienation of Intellectuals in Saul Bellow's World of Fiction
}

\author{
Ramzi Marrouchi ${ }^{1} \&$ Mohd Nazri Latiff Azmi ${ }^{1}$ \\ ${ }^{1}$ Faculty of Languages \& Communication, Universiti Sultan ZainalAbidin, Gong Badak, 21300, Kuala \\ Terengganu, Malaysia \\ Correspondence: Ramzi Marrouchi, Faculty of Languages \& Communication, Universiti Sultan ZainalAbidin, \\ Gong Badak, 21300, Kuala Terengganu, Malaysia. E-mail: ramzi.marrouchi@yahoo.fr
}

Received: October 31, 2019 Accepted: November 27, 2019 Online Published: December 28, 2019

doi:10.5539/ijel.v10n1p314 URL: https://doi.org/10.5539/ijel.v10n1p314

\begin{abstract}
This paper crystallizes how and why Bellow's intellectual heroes in his later novels are men of ideas, dissenters and revolutionists of the age, though marginalized, victimized, degraded, disregarded, and forgotten in spite of their celebrity and contributions to American culture. The reason behind this partly exists in their being idealists, men of imagination and letters and partly because of the spoilt capitalistic American culture. Herzog satirizes the norms of the masses, and ironically and sympathetically is mocked by Bellow himself for his being too utopian. Henderson, Sammler and Humboldt sketch the decline of humanism and the agony of the intellectual. Corde illustrates this humanistic fall through the crisis of the communist system in Romania. Because of this cultural backdrop, American intellectuals are destined to suffer, feel agony and alienation. Here Bellow suggests subversion and deconstruction to the norms of his society. More strikingly, he adopts the strategy of being 'forever en route,' forever re-evaluating one's beliefs and ideals. The madness of his heroes is only a moment wisdom and over consciousness about the necessity of replacing the culture of masses and capitalism. Deeply behind this, Bellow maintains that the promises of the Enlightenment morality - freedom, faith, happiness, altruism, reason, wisdom, humanism, self-autonomy and harmony-have surprisingly turned into their opposites, and have been supplanted by new terms of utilitarian, nihilist, 'irrational' discipline characterized by amorality, illusion, risk and the crisis of knowledge.
\end{abstract}

Keywords: madness, morality, alienation, reason, intellectuals, deconstruction

\section{Introduction}

This paper argues for the way over consciousness engenders the wisdom of Bellow's heroes and their attempts to deconstruct the norms of mass people and low culture. Since deconstruction has been effectively related to modernity and postmodernity; since Bellow's intellectual heroes have been defined in line with madness, subversion, wisdom, deconstruction and alienation in mass society, one investigates, first, the way the heroes are trained in a European intellectual tradition, and how and why they are alienated, marginalized in a society which is dominated by low culture. The themes of human welfare and moral worth, reason and faith as natural law, madness as peace and gift and eventually happiness and human flourishing are fundamental concepts to analyze in order to qualify Bellow's protagonists as alienated, marginalized and laughed at intellectuals who strive to deconstruct the norms of their society.

Deconstructionism is intensely aware of its indebtedness to philosophy. Accordingly, deep affinities are sketched between different types of discourses namely literary and philosophical, subversive and deconstructive which the researcher assumes as a fundamental condition for entering Bellow's fictional world. At this level, the researcher analyzes how and why over consciousness engenders what Bellow calls madness as wisdom, deconstruction as subversion and chaos as life, achievement and humanism. Bellow often coins this with the conflicting poles of high culture and low culture, intellectuals and mass society.

\section{Human Welfare and Moral Worth}

\subsection{Herzog's and Sammler's Romantic Morals}

How does Saul Bellow trace human welfare and 'Man's moral worth in his later novels? How can these concepts be related to the heroes' subversion and deconstruction to mass society and low culture norms? Why does Bellow 
identify his heroes with these intellectual traits and moral values? To answer these three questions, Diane Johnson proposes that one needs to start thinking of Bellow as a "humanist reformer" (Johnson, 1982, pp. 134-40). Susan Glickman takes the idea further to suggest that "[...] Bellow take[s] on the issues of man's place in nature and society, the character of the [humanist] quest, the function of evil, and the roles of will and intellect make [...] the Blake and Wordsworth of modern American letters" (Glickman, 1989, p. 222). Admitting that Bellow's defense of man has been made in the confluence of three main streams: The Enlightenment experience, the Jewish experience and the American experience, John Jacob Clayton proffers:

[...] Bellow's fiction in general is moral; it is not concerned with style [...] nor even with psychological revelation; it considers such moral-metaphysical problems as the demarcation of human responsibility [...] it believes in man and in the potentiality of holiness and joy within the common life, the possibility of meaningful existence. (Clayton, 1979, p. 38)

These concerns are encompassed in the novelist's preoccupation with the aspects of human experience and the qualities of the human personality that lie beyond the subject of modernity. Bellow proposes that one should only act according to the truth of the heart and the benefit of community which is in line with Kant's 'categorical imperatives.' Herzog in Herzog (1964) translates this moral principal through undermining 'the enemies of life,' and celebrating humanism. He asserts:

The point was that there were people who could destroy mankind and that they were foolish and arrogant, crazy, and must be begged not to do it. Let the enemies of life step down. Let each man now examine his heart. Without a great change of heart, I would not trust myself in a position to authority. Do I love mankind? Enough to spare it, if I should be in a position to blow it to hell? [...] let us lie down, men, women, and children, and cry, "let life continue-we may not deserve it but let it continue." (Bellow, 1964, p. 67)

Herzog admits that mass people who belong to low culture "can destroy mankind" because "they are foolish, arrogant, crazy and [ignorant]." He calls them "the enemies of life." Herzog is a university professor, a man of great ideas, a student of such great philosophers as Hegel, Heidegger, Nietzsche, Tocqueville, Rousseau, Spinoza, Kierkeggard, and Spencer, among others. He reads Hegel's The Phenomenology of Mind, a book on "'law of the heart' in Western traditions" (p. 119), and assumes that "Without a great change of heart, I would not trust myself in a position to authority." His two books, Romanticism and Christianity and The State of Nature in $17^{\text {th }}$ and $18^{\text {th }}$ Century English and French Political Philosophy epitomize him as an intellectual humanist who "love[s] mankind, [and cries to] let life continue." In a rebellious gesture to the conformity of his society, Herzog divorces his wife Daisy because she represents a stable, familial, faithful, traditional Jewish woman; and because he wants to give up "the shelter of an orderly, purposeful, lawful existence [...] it bored me, and I felt it was a slacker's life" (p. 103). His happiness lies in his nervous roaming between Chicago, New York, Philadelphia, Vineyard Haven, Europe, and Ludeyville. In his journeys, his quest for a dream wife crystallizes the worth of life:

He tries every type of woman he can: his first wife Daisy is of traditional style; his second wife Madeleine, a modem beauty; Ramona, a mixture of both sexual satisfaction and intellectual delicacy; Sono Oguki, an exotic woman, and many others. His desire for the infinite tends more toward romantic philosophers, intellectuals, and poets like William Blake than toward God and systematic theorists of human mind like Freud and other psychologists. (Rho, 1999, p. 26)

In Herzog's thinking, women have three predominant images that frequently occur in society: the maternal woman, the castrator and the exotic woman. He should end up having that modern, mad, intellectual and exotic one. "Daisy is of a traditional style." Madeleine and Ramona are exotic, modern, and rebellious; and that is why they satisfy his sexual and intellectual thirst. His desire for women is sexual, romantic, intellectual and rational at the same time. Deeply behind this, Rho shows the protagonist as an "intellectual immured in Rousseauian romanticism, not in Aristotelian and Descartesian rationalism" (p. 25). He deconstructs Classicism, especially its uncompromising view of human beings and the supremacy of reason. He subverts and excoriates modem culture, its standardized, industrialized mass culture which produces the vulgar, common man who dominates the modem society. To Bellow's mind, one should act in accordance with mankind happiness; one should suppose, in Herzog's manner, that the love of life is a basic feature of human nature, and, on this assumption, one's moral duty is to count each other person's right to deserve life and happiness. In this respect, Bellow is in line with Hegel's and Kant's ethics of morality to bring the world home and to be satisfied with it. According to Hegel, satisfaction is related to "morality, humanism, true spirit, the happy state, consciousness, reason or pure insight, intellectualism, ethical life, faith" (Hegel, 1977, p. 22). The constructs and unifies both a moral and a rational world which is capable of providing 'Man with hope and meaning'.

Over consciousness engenders what Bellow calls high culture through Mr. Sammler's philosophical meditations. 
Artur Sammler addresses the issues of morality, humanism and intellectualism from a different angle of view. He:

[...] saw the increasing triumph of Enlightenment-Liberty, Fraternity, Equality [...] Enlightenment, universal education, universal suffrage, the rights of the majority acknowledged by all governments, the rights of women, the rights of children, the rights of criminals, the unity of different races affirmed, social security, public health, the dignity of [Man]. (Bellow, 1970, p. 55)

Being utopian, Sammler acknowledges a just system of Global democracy, human rights, and Man's dignity. Humanism, to Sammler's mind, can be translated in the Enlightenment values of: "liberty, fraternity, equality, universality of education, suffrage and human rights." Bellow offers that only the Enlightenment mind with its pure insight and rational faith can establish such a 'happy state' and reinforce Man's moral worth. Assuring the values of 'freedom and necessity, right and obligation as a moral and ethical duty,' Sammler is presented in the novel as a culture collector and a gatherer of civilizations. He was brought up in the European culture of Enlightenment and Holocaust, and has immigrated to America, spending the rest of his life there theorizing for humanism and life. Therefore, Sammler is not completely immersed in either culture, either the European or the American. He knows both. "Named Sammler, which means 'a collector' in German, he figuratively plays the role of the historical collector his name represents" (Rho, 1999, p. 57). Rho proffers that "Sammler almost becomes a modem-day Alexis de Tocqueville, in so far as he is a student of democracy in America, and documents the decline of civility, degradation of culture, and alienation of the intellectual that emerges in the democratized [and capitalized] society" (p. 57).

\subsection{Henderson and Corde: Mythical Journeys and Dictatorship}

Henderson in sketches his view of morality and consciousness through his mythical and imaginary journeys. Unlike Sammler who immigrated to the New World, he escapes it. He runs away from New York and Chicago to the wilderness of Africa:

When I think of my condition at the age of fifty-five when I bought the ticket, all is grief [...] a disorderly rush begins- my parents, my wives, my girls, [...] my habits, my money, my music lessons, my drunkenness [...] I have to cry let me alone. If I am to make sense to you people and explain why I went to Africa [...] I might start with money. I am rich [...] I inherited three million dollars after taxes, but I thought myself a bum, I behaved like a bum [...] I looked into books to see whether I could find some helpful words [...] I have already mentioned that there was a disturbance in my heart, a voice that spoke there and said, I want, I want, I want, it happened every afternoon, and when I tried to suppress it, it got even stronger. (Bellow, 1959, p. 7, 25)

Henderson escapes from the materialism and the capitalism of New York. He does not acknowledge the American dream. He rejects the modern habits of life "my parents, my wives, my girls, my habits, my money, my music lessons, my drunkenness," and looks for redemption and salvation in books and journey. To Henderson's mind, money and material life cause his grief, alienation and loneliness; and it is because of this that "a voice that spoke there [in his heart] and said, I want, I want, I want, it happened every afternoon, and when [he] tried to suppress it, it got even stronger." Tommy Wilhelm cries "Oh, God, let me out of my trouble. Let me out of my thoughts, and let me do something better with myself" (Bellow, 1956, p. 30). Henderson echoes Tommy by giving his search for humanism and morality religious and existential tones.

Herzog addresses God, “[...] thou movest me" (Bellow, 1964, p. 414), rising thereby Man's dire strife for humanism and morality "My God, Who is this creature? It considers itself human. But what is it? Not human of itself. But has the longing to be human. And like a troubling dream, a persistent vapor, a desire," (270). Von Humboldt Fleisher and Charles Citrine reiterate human welfare by reflecting upon what Kant calls categorical imperatives or maxims that regulate Man's moral worth. They inform us that "money wasn't what [they] had in mind. Oh God, no, what [we] wanted was to do good. [We were] dying to do something good. And this feeling for good went back to [our] early and peculiar sense of existence- sunk in the glassy depths of life and groping [...] for sense" (Bellow, 1975, p. 3). They both, in their different ways, experience the fate of the intellectual in the America of the mid-twentieth century. Humboldt has in mind the idea of converting America from a materialistic land to "a new Athens," a country of "Platonic concepts of truth and beauty," transforming Greenwich Village "from a province into a cultural capital, importing ideas from the whole European tradition and adapting them to the sprawl and chaos of contemporary America" (Siegel, 1978, p. 148; Atlas, 1977, p. 143). Citrine is supposed to be a culture-maker, insisting in the novel that "everything possible must be done to restore the credit and authority of art, the seriousness of thought, the integrity of culture, the dignity of style" (Bellow, 1975, p. 249). Citrine and Humboldt are men of letters, utopians, theorists and revolutionists of the age. Rho maintains that "they are marginalized, victimized, degraded, humiliated, disregarded, and forgotten in spite of their celebrity and their 
contributions to American culture, partly due to their romantic, unrealistic and anachronistic characteristics, but mainly because of the fundamentally barren American cultural soil (Rho, 1999, p. 98).

Albert Corde is an intellectual like Herzog, Sammler, Humboldt and Citrine. He started his career as a journalist, then a professor, and eventually a dean at a Chicago college. Echoing Henderson and Herzog, He cannot escape the power of ideas, nor can he get rid of the duty of thinking. He assumes that "If he didn't pull himself together, he'd suffer from random thoughts. Those were the worst — they ate you up" (Bellow, 1982, p. 135). Like Humboldt and Citrine, he reads Great Works of Shakespeare, Dante, Milton, Plato, Romantic poets, the logic and morality of the Enlightenment, Hegel, Kant, among others. He identifies himself with the poet "When Rilke had complained about his inability to find an adequate attitude to the things and people about him, Corde had thought, Yes, that's very common - that's me" (p. 61). Unlike Herzog's speculations about logic, he is emotional, intellectually balanced and a faithful and lovable husband "He was also misleadingly domestic. She (his wife) had never noticed how many household duties he took on - the groceries, cooking, vacuuming, washing windows, making beds" (p. 260). Throughout his trip to Bucharest, Romania, it does not take him longer than two weeks to understand the authoritarian nature of Communism and its illusive and grand discourse, while it took longer periods for other intellectuals as Richard Wright in Chicago, Arthur Koestler in Germany, Louis Fischer in Russia, Andre Gide in France, and Stephen Spender in England. After his escape from Rumania, he realized that "the communist machine has winnowed out the grain and retained only the chaff of Western culture" (p. 9), and that "The same old capitalist society has been re-established, a new and terrible despotism crushing and exploiting man, with all the abject and servile mentality of serfdom" (p. 176).

In their attempts to free themselves from the different sorts of dictatorship of mass people and low culture, these subjects are more in accordance with Hegel than with Kant. In fact, Sammler strives to bring together peace and war, science and humanism, life and death, virtue/sublime and materialism, history and fiction, loss and morality. Herzog depicts wisdom and madness, reason and faith, love and death, revenge and sacrifice, literature and philosophy. Henderson traces family and society, freedom and necessity, hope and fate. Eventually, Humboldt envisions boredom and meaning, poetry and philosophy. On this view, Bellow admittedly endorses that only a sense of unity and 'absolute knowledge' in the Hegelian way can reinforce Man's moral worth and the human welfare in the face of the deconstructive forces of mass people and low culture.

Given these assumptions, three questions crop up, a) how should these protagonists subvert and deconstruct all sorts of mass society domination and low culture? b) How can over consciousness, morality and intellectualism engender deconstructive strategies to the world, things, ideas and people? c) And why is such eagerness to deconstruct the norms of mass society and low culture? These questions have long been major concerns of Bellow's moral theory and deconstructive insights. The answers he suggests in his writings vary. More interestingly, Bellow's suggestions typically depend on the position he takes on a fourth question: To what extent can one 'bring the world home and be satisfied with it?'

\subsection{Madness and Humboldt's Lost Gift}

The answers which Bellow provides to these questions radically differ. In this sense, he proposes, on the one hand, that only intellectuals, thinkers, theorists and philosophers can promote human welfare and keep Man's moral worth. However, he paradoxically subverts this idea by denying them, his intellectual heroes, the ability to assure a genuine respect to their moral theories. This gesture makes Man a victim of his own rational faculties. In Humboldt's Gift (1975) for instance, Bellow sketches this paradox by tracing both the moral duty of intellectuals and the inability to safeguard their moral legislations in practice. He articulates:

There came a time (Early Modern) when, apparently, life lost the ability to arrange itself. It had to be arranged. Intellectuals took this as their job. From, say, Machiavelli's time to our own this arranging has been one great gorgeous tantalizing misleading disastrous project. A man like Humboldt, inspired [...] was brimming over with discovery that the human enterprise, so grand and infinitely varied, had now to be managed by great persons. (p. 29)

Satirically enough, Bellow subverts this by drawing a sharp sckepticism in Humboldt's mental faculties. He doubts his capacity as an intellectual to put his moral theory into practice. Arranging modern life has become "one great gorgeous tantalizing misleading disastrous project." Humboldt, the inspired poet and thinker, is acknowledged by great persons; yet, ironically enough he "lost the ability to arrange life," his life. He is only a victim of his genius and intellectual reflections. Bellow points out:

Poet, thinker, problem drinker, pill-taker, man of genius, manic depressive, intricate schemer, success story, he once wrote poems of great wit and beauty, but what had he done lately? Had he uttered the great words and songs he had in him? He had not. Unwritten poems were killing him. (p. 25) 
Humboldt "wrote poems of great wit and beauty; [However] unwritten poems were killing him." Humboldt's poems depict life, beauty and happiness. They theorize for a moral world where human being keeps dignity. He is a man of genius and ideas. He is a good storyteller. The chance of uttering his "great words and songs" entails his intellectual insights against the power and the dictatorship of the masses. Unfortunately, his "Unwritten poems were killing him." Differently put, his unpublished views about life and humanism, unlegislated moral laws in the unpublished poems were "tantalizing" him. He sarcastically admits that he cannot bring a real change to the world. Herzog's imaginary and philosophical letters (Bellow, 1964, pp. 1-20) underpin that morality is a matter of consciousness of time, that existence must be lived, experienced to the end since "only at the end of its journey [that] consciousness is ready to understand what has happened to it and why [...] to think reflectively and self-consciously about the categorical shifts that have led it forward from one problematic position to the next" (pp. 112-136), and eventually to legislate for its moral and ethical norms. Henderson the Rain King, through his imaginary journey to the wilderness of Africa, mirrors a quest for morality through the journey of the spirit that "[...] may purify itself for the life of the spirit, and achieve finally, through a completed experience of itself, the awareness of what it really is in itself" (Bellow, 1959, pp. 60-70). According to this intellectual and subversive nature of mind, Bellow has proved to be in line not only with the Hegelian sense of the Enlightenment morality, but also with the young Hegelians like Heidegger, Nietzsche, Ardent, Wittgenstein a phase of thought that Thomas McCarthy defines with "historical crossroads" (McCarthy, 1987, p. 1).

Sammler aggravates the moral lessons of the Holocaust. He admits that human beings [must] be capable of telling right from wrong even when all that have to guide them is their own judgment (Bellow, 1970, pp. 22-29). He, by the same token, acquaints Asa Leventhal in Dangling Man (1947) with Nietzsche's ideals of the 'Super Man' and the will to power as he decides to go to the war for moral and ethical ends. Moral worth and human welfare are justified in these instances by a matter of intellectual emotion, passion and humanism rather than a matter of rationality and materialism. In short, one can admit that the theory of morality, in Bellow's view, is akin to the sense of time, being and consciousness in which is strikingly identified with the wisdom of intellectuals, and their ceaseless attempts to deconstruct the existing norms of their society.

Taking this critical position, one can suppose that Bellow falls here into the logocentric trap described by Derrida. In this, his heroes advocate the Enlightenment philosophy of morality initiated by the early Greek philosophers; and yet, they fail to subvert its most sublime ideals. This hypothesis proceeds to suggest that the novelist sharply depends upon the classical hierarchy which is based on, in a typical structuralist strategy, binary oppositions of good and bad, moral and rational, high thinking and low thinking, intellectuals and mass society, and ultimately high culture and low culture to build his fictional world. What Bellow simply does is that he sets to exchange one negative aspect of morality by a formerly positive one, erecting a hierarchical system that privileges morality and passion over rationality.

One way to respond to this allegation is that Bellow perceives this situation as unsatisfactory, and here where he, through his intellectual heroes, starts his strategies of subversion. Derrida provides a way out, and a scholarly climate characterized by deconstruction and 'Post-Enlightenment.' This infuriated Bellow's intellectual heroes to deplore and assess the findings the Enlightenment, logocentrism and metaphysics. What follows is that, in order for these heroes to penetrate into the fundamental assumptions of the Enlightenment moral philosophy, and subvert them at a second stage, Bellow sets out to study the foundations of metaphysics which recommend themselves as a guide for the critique of the Enlightenment. The early Bellow demystifies the ethics of humanism, the virtues and ideals of morality, happiness, reason, faith, justice, the goal of human life which are concomitant with the classical tradition of metaphysics. However, in his later novels he 'distances' himself from his early career hoping to carry out the enterprise of the self-overcoming of metaphysics. His intellectuals faced multiple types of dictators beginning with the illusive, totalitarian and authoritarian norms of the Enlightenment reaching the dogmatic and low thinking of the masses and low culture.

To understand this startling turn it is useful to recall that Bellow has already begun his literary career reflecting upon the Enlightenment's 'rejection' to the metaphysical thought. He develops Norris's claim that the Enlightenment is a break with the metaphysical tradition, Kant's celebration of reason in relationship with Hume's view of passion and morality, Hegel's absolute unity, the dialectical spirit and the function of philosophy and the duty of philosophers. Perhaps, it is in this way that Bellow was regarded as an intellectual historicist, to Judie Newman's mind, who believed that "Each individual is [...] a child of his time; thus [literature], too, is its own time comprehended in thoughts" (Newman, 1989, p. 11).

\section{Reason and Faith as a Natural Law}

Bellow's reading to reason and faith offers three different viewpoints. First, it highlights the symmetries between 
the themes of wisdom, intellectualism, reason and faith inherent in his later novels. Second, it unravels how Bellow believes that reason and faith, rationality and religion should not contradict each other, a gesture that recalls Hegel's absolute unity. Third, it outlines the heroes over consciousness and their attempts to deconstruct the values of mass people and low culture. Reason and faith operate as elements that qualify Herzog, Henderson, Sammler, Humboldt and Corde with intellectualism, wisdom and alienation. These concepts are deployed at this level to unravel the way the heroes' over consciousness about materialism, science and rationality on the one hand and religion, God and humanism on the other hand aggravates their gestures of deconstructing the norms of mass society.

In his Writings on Religion (2002), John Locke associates morality with reason and faith. He, by this token, strikingly admits that the happiness of Mankind is hinged on the presence of God, the maker of the universal law, and the reason of Man that is going to rationalize this faith. He elaborates:

To establish morality therefore upon its proper basis and such foundations as may carry an obligation with them we must first prove a law which always supposes a law maker, one that has superiority and right to ordain and also a power to reward and punish according to the tenor of the law established by him. This sovereign law maker who has set rules and bounds to the actions of men is god their maker whose existence we have already proved. (Locke, 2002, p. 350)

Morality establishment depends on law and law maker. The law is religion which demands faith. The law maker is God himself. This God has the superiority, right, and power to "reward and punish according to the tenor of [his] law." Man's reason rationalizes the faith and belief in God in order to be rewarded. Morality and humanism are hinged on this juxtaposition between reason and faith. The Enlightenment considers this as a natural law (Kant, 1970, p. 54). Hume admits this thinking, though he acknowledges the primacy of passion over reason. He supports this argument by admitting that morality is created by God's command, and therefore, there is no morality without obedience to its creator (Hume, 1978, p. 10). Accordingly, "reason can only be the slave of passions, and can never pretend to any other office than to serve and obey them" (p. 20). The impulse of human action does not rise from reason, but it is directed by it. Kant repeatedly emphasizes that one should act in accordance with moral ends and rational means. This "presupposes that the several formulas of the Categorical Imperative are morally fundamental, that rationality is not exclusively instrumental, and that moral agents are to be seen as legislators of moral laws as well as subject to them" (p. 7). Derrida posits the idea anew by introducing the metaphor of the book of God. He quotes a saying of Jaspers "the world is the handwriting of another, [God], never fully legible world." Now this book which is written in God's handwriting never existed, there are only traces of it which Derrida calls "the book of reason [...] [since] God is said to have given us the use of this pen" (Jaspers, 1976, p. 10).

Bellow's awareness of this background has left its imprints on the way he perceives reason and faith in accordance with the heroes' deconstruction to the norms of their society. Herzog is an emblematic epitome in this case. He shows a careful awareness of the connections between reason, faith and morality. He builds his thinking on the assumption that "God may well be the pure idea of reason" (Kant, 1965, p. 35). He endorses that only reason and faith can guarantee Man's moral worth against the nihilism of the low culture of his society, and assure a "steady progress" to human civilization (Bellow, 1964, p. 225). However, such a belief should be regarded as the outcome of long sckeptical meditations over the nature and the function of God. Herzog begins narrating his story, in a typically positivist move, with questioning the belief of his generation "What is the philosophy of this generation? Not God is dead, that point was passed long ago. Perhaps it should be stated Death is God [...] if the old God exists, he must be a murderer. But one true god is Death," (p. 53) again "God is the evil" (p. 354), and he unexpectedly ends up with all that which the Enlightenment believes "The victory of [God], not of rationality [...] our own murdering imagination, our human imagination which starts by accusing God of murder [...] turns out to be the great power" (p. 354) and again "Dear God! Mercy! My God [...] Thou King of Death and Life!" (p. 370), "Thou movest me" (p. 414). Herzog's reflections on God shift from suspicion and death to acknowledgement and life. His generations confess that "the old God is death; the true God is a murderer" (p. 372). God is acquainted with negativity and nihilism. Later, he enigmatically acknowledges the power, rationality and victory of God. God is the king of life and death, the source of morality and happiness "Dear God! Mercy! My God [...] Thou King of Death and Life!" Herzog is morally moved by the miraculous power of God. He confirms that God is, in a Cartesian sense, naturally innate in the human mind. Faith, He maintains, is a clear idea of thinking, an object of a rational and spiritual knowledge. Bellow's sense of subversion, from negating the presence of God to asserting 'his' being the stream of life and the pure reason, stems from the postulate that God [is] a unifying idea in the order of speculative reason and a postulate in the moral order of practical reason.

Bellow's later novels are replete with such instances of search for harmony between reason and faith, rationality and religion, mind and God. When Henderson in Henderson the Rain King (1959) faces death in the jungles of 
Africa; when he fights against the savage warriors of the Warriri tribe; when a lion attacks him in the forest, a celestial light of God, the savior from death, appears to his spirit. He bitterly prays:

Oh my God, whatever you think of me, let me not fall under this butcher shop. Take care of the king. "King for God's sake!" I wanted to cry. "What have we got into?" [...] God curse all veins and creepers [...] "Your Highness," I said, and raised my weeping voice, "what have you pulled on me? I should have been told what I was getting into Was this a thing to do to a friend?" Without reopening his eyes, but smiling in his increasing weakness the king said, "it was done to me [...]" Then I said, "your majesty, move over and I'll die beside you. Or else be me and live; I never knew what to do with life, and I will die instead." I began to rub and beat my face with my knuckles, crouching in the dust between the dead lion and the dying king. "The spirit's sleep burst too late for me. I waited too long, and I ruined myself with pigs. I'm a broken man. And I will never make out with my wives. How can I? I will follow you soon. These guys will kill me. King! King!” (pp. 258, 259, 262)

The idea might seem contradictory in Henderson's prayers for life in the beginning and his longing for death in the end; however, the storyteller is assuredly suggesting that death becomes a metaphor of unity with God. When Henderson faces the lion and death in Africa, he prays for life "Oh my God let me not fall under this butcher shop. Take care of the king." While facing his finitude, death, faith seems that all Henderson has. At the moments of weakness, "[he] wanted to cry [...] raised [his] weeping voice" to pray for mercy and life for himself and the king of the tribe. The metaphor of unity with God appears through his readiness to sacrifice instead of the king "your majesty, move over and I'll die beside you. Or else be me and live; I never knew what to do with life, and I will die instead." Henderson's escapism from the material context of New York and the habits of mass society marks the beginning of this unity between faith and reason, God and Man, feeling and intellect, religion and philosophy. As a matter of fact, Henderson loses faith in his 'money, factories, power, habits, New York, wives,' in other words, rationality and science in America, and regains a spiritual release with Romilayu, his guide in Africa; he loses faith in materialism and regains it in God and reason. He rejects the world of masses, materialism, lights in New York, and welcomes God, faith and intellectual tranquility in the wilderness of Africa. More strikingly, the wilderness, Romilayu, the tribes in Africa, the dying king of the Wariri tribe, Henderson and all other elements that shape the story of the journey acquire a symbolical dimension as they ultimately stand for Jesus' dramatic trip to overspread his mission. Behind this, Bellow overcomes the polarity of reason and faith and shows, in a typically Hegelian manner, how religion and faith should express an intellectual and philosophical outlook, albeit in a non-philosophical form. He, by the same token, proposes that any religious consciousness should adopt the faith that upholds a rational view of the world. In other words, Saul Bellow hopes to show that any faith should be incorporated with reason and not rejected from it, and that Man's moral worth should be converging on rather than departing from the rational insights of reason.

Sammler, Corde and Humboldt are outspoken expressions of the harmony between reason and faith, intellectualism and God which generates Bellow's attempt to aggravate Man's moral worth. L. H. Goldman views these subjects as "[...] heroes, intellectuals, sufferers, strugglers, survivors, [philosophers], believers. They are humanists: they are all concerned with dignity (theirs and others), humanity (or lack of it), [faith (in relationship with reason)]" (p. 51). Sammler In Mr. Sammler's Planet (1970), survivor of the holocaust, offers a utopian homeland where both reason and faith can assure Man's dignity and freedom "on the moon, people would have to work hard simply to stay alive, to breathe, [to think, to pray]" (p. 64). Assuming that "sexual madness was overwhelming the Western World" (p. 63), that "money, power, [science], do drive people crazy" (p. 62), that the modern world has become a spectacle, that life is dominated by the habits of the masses, the features of low culture, that God is already dead and will remain as such forever, and that the Enlightenment reason gives rise to the century's greatest crimes and atrocities (p. 63), Sammler interestingly confirms that there should be a moral revolution in the light of the Kantian legacy which admits that reason is blind without faith and faith in its turn is crippled without reason (pp. 33-65). Sammler's intellectual speculations over God and reason, spirit and civilization can only epitomize the over consciousness of an alienated intellectual. The death of God entails disillusionment and the tragic fate of both the capitalist and the communist regimes. He points that "Both the U.S.A. and the U.S.S.R. were [. . . ] utopian projects. There, in the East, the emphasis was on low-level goods, on shoes, caps, toilet-plungers, and tin basins for peasants and laborers. Here it fell upon certain privileges and joys. Here wading naked into the waters of paradise, etcetera" (p. 158). Humboldt in Humboldt's Gift (1975) takes the idea further to state that "America was God's experiment. Many of the old pains of mankind were removed, which made the new pains all the more peculiar and mysterious" (p. 162).

God in The Dean's December (1982) is meant communism, socialism, and whatever ideology the Left tradition promises. Faith and reason are combined to result such a historical consciousness about modern civilization. 
Before unfolding his novel The Dean's December, Bellow starts with the following introductory remark, that "Although portions of this novel are derived from real events, each character in it is fictional, a composite drawn from several individuals and from imagination. No reference to any living person is intended or should be inferred" (p. 3). Bellow not only evades all the expected polemics of the Left, but also awakens its attention as to the illusive promises of the utopian ideology - communism. Christopher Lasch in his The Agony of the American Left in the 1950s (1969) declared "the end of deep political conflict in the West, the end of utopian attempts to reconstruct society" (p. 171). Echoing Bellow's trip to Jerusalem in To Jerusalem and Back: A Personal Account (1970), the protagonist, Dean Albert Corde, examines Romania with curiosity at first, but as his story develops he becomes "a hungry observer of the communist society" (p. 8). The first impression Corde gets in Bucharest is a feeling "like tying a plastic bag over your face and telling you to breathe deep," that which he escaped in Chicago (p. 6). The metaphorical death of God summons the unbearable conditions of life in Romania. Bucharest is cold. It is no longer a Paris city in December. The streets are full of baggers; cemeteries are full of crazy people and strangers. Intellectuals are rejected. Police officers, colonels and dictators are considered the real leaders and saviors of the country. "The Dean Corde cannot bear this kind of life" (Rho, 1999, pp. 147-152). The ideology of communism fails as it increases the suffering of people. Vlada, Minna's friend and a Rumania-American scientist at Chicago, reminds Corde of the characteristics of Rumania "It's nothing to them that you're a dean, but it counts that you're a journalist. Also, that you're connected with the Ambassador and with the famous columnist Mr. Spangler" (p. 282). The ruler, dictator, like that Corde essayed to escape from Chicago as Rho maintains "plans to rule Rumania under the name of communism and systematization; in other words, Rumania is a machine to him. And it turns out to be a huge cage or a prison. All the means to strip individuality comprise one device. Censorship and bugs control the characters like prisoners" (p. 153).

Ravelstein in Ravelstein (2001), a professor of history and philosophy, reflects on "antiquity, Machiavelli, Hobbes, the Enlightenment, and then by way of Locke, Montesquieu, Rousseau onward to Nietzsche, Heidegger - to the present moment, to corporate high tech America, its culture [...] its politics" (p. 46). He believes that in the modern age "no real education was possible in the [Western] universities except for aeronautical engineers, computerists, biology, physical science and the like" (p. 47), while God has already been decentralized, dehumanized and finally rejected from the focus of the intellectual circles. Ravelstein assuredly declares that in this somber age it is the duty of the intellectuals to guard Man's essence, and that happiness is still required, and faith is again brought in to do the job (p. 48). The Adventures of Augie March (1953), The Victim (1947) and Dangling Man (1944) represent another significant instance concerning the awareness of the scrupulous connections between reason, faith and morality. In fact, Daniel Fuchs in his Saul Bellow: Vision and Revision (1984) has insightfully assessed them as the recreation of the philosophy of Judaism as intertwined with the project of the Enlightenment (pp. 22-31). Joseph in Dangling Man (1944) incarnates the problem of choice between reason and faith. Satirically enough, he is a war casualty who has not fought, not even enlisted to be a soldier in the war. Joseph begins to realize that his moral norms are highly dependent on his responsibility for choosing either to survive since "there is no dignity anywhere, nothing but absurd falsehood" (p. 48), or to follow his faith and end up becoming a victim, like Asa Leventhal, "It is our humanity that we are responsible for [...] our dignity, our [faith]" (p. 167). Asa Leventhal in The Victim (1947) begins where Joseph ends up. That he bears moral responsibility overtones a problem of conflicting concepts and ideals between egoism and altruism, Man and God, the ethics of the individual and the norms of society. Believing that "It's bad to be less than human and it's bad to be more than human" (p. 20), Asa stresses the biblical narrative and the Enlightenment morality which usually appear as a covert metaphor in Bellow's narratives. Bellow has been always claiming that Augie March in The Adventures of Augie March (1953) is "a comic subject about death" (pp. 224-228). Death, being the metaphor for the ultimate unity with God, underlines the starting point and the end which Bellow's subjects seek to achieve.

Bellow's autobiographical account in his To Jerusalem and Back: A Personal Account (1970) draws consistency between reason, faith and morality. Although the book sketches the personal journey of the author by describing his real trip from Chicago to Jerusalem with a political and economic reflection on the context of the Middle East in the seventies, Bellow says in the opening "It is my childhood revisited" (p. 2). The preposition "back" offers three different meanings a) returning back to Chicago at the level of the story, b) recollecting Bellow's childhood at the level of memory, and c) highlighting reciprocal and metaphorical movements in space from Chicago to Jerusalem and in time from adulthood to childhood. Interestingly, John Jacob Clayton regards the journey as a never-ending movement from Man to God:

In the world of distraction, the world in which the ego, the social self, moves, man cannot be saved. But there is always another world in a Bellow novel: it is a world of love, of search for the light of God and the will of God, a world in which the person is no fool, or is a holy fool, in which the soul [...] is worthy of salvation. (p. 
287)

Clayton's claim presupposes that Chicago stands for reason, rationality, modernity, materialism, utilitarianism, lights, power and money, whereas Jerusalem represents faith, God, soul, salvation and purity. Like Joyce's 'Dublin' and Blake's 'London,' Chicago, to Bellow's mind, is a modern metropolis where man is always 'other,' alienated, degraded, humiliated and eventually rejected. Jerusalem, however, becomes a metaphor for a spiritual faith and eternal unity with God. It is in this way that memory, recollection and childhood become a second metaphor for Man's moral worth since the novelist sought to unite the further connotations of space, as highlighted in Chicago and Jerusalem, with memory, as epitomized in recollections and remembrances. Bellow's journey entails "a world of love, of search for the light of God and the will of God, a world in which the person is no fool, or is a holy fool, in which the soul [...] is worthy of salvation." Man's essence becomes highly dependent on the connections between reason and rationality in Chicago, faith and purity in Jerusalem and Bellow's recollections. What is more striking is the novelist's tendency to exploit two opposite concepts: reason and faith, which overtone the extensively negotiated relationship between Man and God in the enlightenment, not to reinforce the paradox they apparently suggest but to aggravate their contribution to assure Bellow's theory of morality and humanism.

Bellow maintains the primary importance of his intellectuals as moral agents seeking to promote human welfare in ways which accord with reason and faith, rationality and religion, man and God. Although his heroes start to reflect on reason and faith by referring back to metaphysical issues, they deliberately mock its being satirized and ridiculed in modern American cultural life. Their being intellectuals trained in the European traditional and Enlightenment thinking valorizes their over consciousness about the problems of the age or what Bellow himself calls their high culture; and ironically, decenters them from the heart of the American intellectual scene. Bellow takes two contradictory positions: he sympathetically satirizes them as men of only ideas and letters, and simultaneously censures American mass society and low culture as the primary cause of their problem and alienation.

\section{Madness as Peace and Gift}

In what way does Bellow redefine the concept madness? Admitting that he exalts madness, contrary to the Foucauldian fashion, and elevates it to a state of peace and gift, wisdom and high culture, how does it intensify the over consciousness and the wisdom of his heroes? How and why does it help deconstruct the norms of mass society and low culture? To answer these questions, one should first acknowledge that Bellow belongs to a Western cultural paradigm that acquaints madness with intellectuals, wisdom and Man's moral worth. Although this tradition has been sketched in Michel Foucault and Jacques Derrida, yet Taylor Donnelly in his Vogue Diagnoses: The Functions of Madness in Twentieth-Century American Literature (2012) states that its roots could be traced back to metaphysics and the Renaissance (pp. 1-6). Foucault and Derrida devoted more attention to the concept of madness. On this view, Foucault in his Madness and Civilization (1965) believes that "[...] madness has been recognized as part of truth" (p. 20). Derrida paradoxically states that it should not belong to that sort of metaphysical truth. According to him, madness is already there, in the origin of geometry (Derrida, 1982, pp. 2229), to recall Husserl; in other words, it is a form of knowledge in 'the structure of thought' to borrow Foucault's terms (Foucault, 1973, p. 31). Madness in the Derridean sense begins only with the moment of skepticism about metaphysics, and the decentralization of the Enlightenment reason.

Foucault examines the issue from two opposite angles a) madness as a phenomenon in history which is related to unreasoned people who are confined, marginalized and finally rejected and excluded from society, and b) madness as a kind of knowledge to cure unreason in the age of reason. These views find their way to Bellow's fictional world which does not only show his awareness of this theoretical edifice, but also places him in a position that echoes Derrida's perpetual equivocation to the metaphysical thought. Foucault declares that "unreason becomes the reason of reason [...] I had been mad enough to study reason, I was reasonable enough to study madness" (p. 55), implying that in order to achieve peace, wisdom and morality one should first experience madness. From his part, Derrida insists that one should question the foundations of metaphysics and subvert them in order to understand Man's moral worth. The purpose of that is to liberate the power of reason from the authority of unreason, the sense of wisdom from the non-sense of madness.

Herzog reflects this intellectual speculation over the concept of madness as he starts narrating his story. His primary words in the story "If I am out of my mind, it's alright with me" (Bellow, 1964, p. 7) overtone his high and lofty thinking. In a Derridian tone, they implicitly underpin the kind of the low thinking of masses which he undermines and ignores. He continues relating his story as follows:

Some people thought he was cracked and for a time he himself had doubted that he was all there but now, though he still behaved oddly, he felt confident, cheerful, clairvoyant, and strong. He had fallen under a spell 
and was writing letters to everyone under the sun. He was so stirred by these letters that from the end of June he moved from place to place with a valise full of papers. He had carried this valise from New York to Martha Vineyard, but returned from the vineyard immediately, two days later, he flew to Chicago, and from Chicago he went to a village in Western Massachusetts. Hidden in the country, he wrote endlessly, fanatically, to the newspapers, to people in public life, to friends and relatives and at last to the dead, his own obscure dead, and finally the famous dead. (p. 7)

Herzog is torn between what the masses think about him "some people thought he was cracked," and what he is "he had doubted he was all there." He is dangling between nihilism and existence, his being out of his mind and his being intellectual. Madness is deepened when he asked for help from his old friends "Dear Wanda, Dear Zinka, Dear Libbie, Dear Ramona, Dear Sono, I need help in the worst way. I am afraid of falling apart. Dear Edvig, the fact is that madness has been denied me. I do not know why I should write to you at all" (19). The female exotic figure attracts him and helps show what kind of protagonist he is. Wanda, Zinka, Libbie, Ramona and Sono offer release and a kind of psycho sexual-sanctuary for the doubly victimized hero, Herzog. Ramona remains at the central of Herzog's intellectual commitment "Dear Ramona, I think your wisdom gets me (p. 25), you are a great comfort to me. We are dealing with elements more or less stable, more or less controllable, more or less mad" ( $\mathrm{p}$. 26), residing as a pre-marital or extra-marital love object. Inspite of his odd behaviors, he wins struggle against the deconstructive forces of society. He "felt confident, cheerful, clairvoyant, and strong." His madness lies in his failure to cope with space. He cannot settle in any place as he kept ceaselessly moving from one city to another. He travels from "New York to Martha Vineyard, but returned from the vineyard immediately, two days later, he flew to Chicago, and from Chicago he went to a village in Western Massachusetts." This fidgety reiterates his endless search for hope and life which is metaphorically translated into his letters to everyone under the sun. Hidden in the country, he writes letters to poets, philosophers, politicians, theorists; he writes "endlessly and fanatically to the newspapers, to people in public life, to friends and relatives and at last to the dead, his own obscure dead, and finally the famous dead."

Bellow admits that Herzog's wisdom lies in transcending his failure to communicate with the masses to addressing intellectuals. His letters to famous intellectuals epitomize what Bellow calls the high culture to which he belongs. He investigates the history of madness archeologically "In my view I tried to suggest that clinical psychologists might write fascinating histories. Megalomania for the Pharaohs and Caesars. Melancholia in the Middle Ages. Schizophrenia in the eighteenth century [...]" (p. 99), and confesses that mad figures end up ruling the world and "madness always rules the world" (p. 99). Historically and clinically, madness has appeared with different images as megalomania, melancholia and schizophrenia. For Herzog, madness is over consciousness and subversion; it is the deconstruction of nihilism and death. He "could not allow himself to die yet. The children needed him. His duty was to live. To be sane, and to live, and to look after the kids. This was why he was running from the city now, overheated, eyes smarting" (p. 38). Behind this, Bellow informs that madness is no longer a state of mind throughout which one loses his rational faculties; rather, it is a moment of consciousness and deconstruction which intellectuals adopt to become moral legislators and bring some change to the world.

Humboldt and Charles Citrine are representatives of madness as wisdom and over consciousness. Humboldt is a famous American poet of the 1930's and the 1940's, praised by T.S. Eliot and Conrad Aiken, spotlighted in major newspaper book reviews and critiques. Citrine takes Humboldt's place after Humboldt declines in the 1950's. In his poems, Humboldt reflects on "history, poetry, philosophy, beauty, love, waste land, alienation, politics, the unconscious, then, now, birth, death, [...] William Blake, Proust, Milton, Virgil, Marvell, Balzac, Marx, Freud, Hegel [...]" (Bellow, 1975, pp. 6-14). Being manic depressive, he praises madness by celebrating sublime, silence; he writes poetry and quotes Shakespeare. Charles Citrine interestingly describes Humboldt as a "Poet, thinker, problem drinker, pill-taker, a man of genius, manic depressive, intricate schemer, success story, he once wrote poems of great wit and beauty [...] unwritten poems were killing him" (25), showing that he dies reading the poems of Yeats and Hegel's Phenomenology. The two characters are men of ideas. Rho describes them "They are almost forgotten at the end of their lives. They are becoming lunatic; they are exploited by a non-artist crowd" (p. 100). They tell the story of a whole generation of Jewish-American losers, and Bellow himself is a telling example of that. In his essay "The Isolation of Modem Poetry," in Selected Essays of Delmore Schwartz (1970) Delmore Schwartz traces the cause of Humboldt's lunacy:

The fundamental isolation of the modem poet began not with the poet and his way of life; but rather with the whole way of life of modem society. It was not so much the poet as it was poetry, culture, sensibility, imagination, that were isolated. On the one hand, there was no room in the increasing industrialization of society for such a monster as the cultivated man; a man's taste for literature had at best nothing to do with most of the activities which constituted daily life in an industrial society. (p. 7) 
Schwartz ascribes Humboldt's lunacy to the isolation of the poet in modern life and even more strikingly to "the whole way of life in modern society." With the massive industrialization and mass factory production system in America, Schwartz confesses that only men of letters are destined to suffer. Humboldt informs Citrine that "Monopoly capitalism has treated creative men like rats" (Bellow, 1975, p. 135). Men of letters have nothing to do with "the increasing industrialization of society," their intellectual, utopian and imaginary visions do not find any way in "the activities which constituted daily life in an industrial society." Poetry becomes a dangerous occupation in America as it makes poets strange and alienated beggars. This business spirit is the root of the American culture. Richard Hofstadter, a cultural historian, indicates in his Anti-intellectualism in American Life (1966) that "it was business $[\ldots]$ that isolated and feminized culture by establishing the masculine legend that men are not concerned with the events of the intellectual and cultural world. Such matters were to be left to women" (p. 50). Humboldt's deep awareness about the radical economic, political and social changes alienates him in the academic community as well as the non-academic society. The example of this is his failure to get a permanent chair at Princeton University after his temporary teaching there. Bellow summons Harold Rosenberg's saying that "Marx[...]conceives the artist as the model man of the future" and "Hegel's Historical Men or World-Historical Individuals [...] through whom truth operates and who have an insight into the requirement of the time, who divine what is ripe for development, the nascent principle, the next necessary thing" in his essays "A World Too Much with Us," and "Machines and Storybooks: Literature in the Age of Technology" (qtd. in Bellow 1: 51). He agrees with both Hegel's and Marx's claim that artists should not be alienated in their field, that no one can replace their work as they depend on their imagination and inspiration. Now, if Bellow's, Marx's and Hegel's theory is reasonable then Humboldt should have been accepted in Princeton University. More bitterly, "he could not find a stable job at any university which added further anxiety to his innate anxiety" (Rho, 1999, p. 105).

Orlando Huggins illustrates Humboldt's case. He is another intellectual in the novel who is destined to suffer. Like Philip Rahv, Lionel Trilling, Irving Howe, and Dwight Macdonald, he is a leftist intellectual who discussed Marxism, Stalinism and Capitalism. He is:

The Harvard radical of the John Reed type, one of those ever-youthful lightweight high-spirited American intellectuals, faithful to his Marx or his Bakunin, to Isadora, Randolph Bourne, Lenin and Trotsky, Max Eastman, Cocteau, Andre Gide, the Ballets Russes, Eisenstein- the beautiful avant-garde pantheon of the good old days. (Bellow, 1975, pp. 321-322)

In his Alienation of Intellectuals in Saul Bellow's Later Novels (1999), Heongyun Rho interestingly elaborates on the previous description of Orlando Huggins as follows:

$\mathrm{He}$ is forgotten, and alienated from the center of American culture. He is found at a New York pub still lecturing on those old ideologies to the drunkards, being regarded as one of the decrepit relics. American society doesn't need talkative dissenters and revolutionists in the seventies. They are gone with Daniel Bell's exclamation, "the end of ideology." In a way they are victims of the Age. (p. 108)

Humboldt and Huggins reach the point that "To the high types of Martyrdom the twentieth century has added the farcical martyr. This $[\ldots]$ is the artist. By wishing to play a great role in the fate of mankind he becomes a bum and a joke" (Bellow, 1975, p. 345). Their over consciousness about the issues of the age leads them to suffer, to be mad in the eyes of common people and mass society; they become 'martyrs'; when they seek for an influential position in society, they ironically "become a bum and a joke." Humboldt supports Adlai Stevenson in the elections of 1952 not only because he thinks he can beat Ike, or even because he a man of culture, but also because he believes that "Culture would come into its own in Washington" (p. 25), and he might be situated in the heart of the intellectual scene in America. He addresses Charles Citrine:

"If Stevenson is in, literature is in - we're in, Charlie. Stevenson reads my poem [...] Stevenson carries my ballads with him on the campaign trail. Intellectuals are coming up in this country. Democracy is finally about to begin creating a civilization in the USA. That's why Kathleen and I left the Village." [...] Stevenson was Aristotle's great-souled man. In his administration cabinet members would quote Yeats and Joyce. The new Joint Chiefs would know Thucydides. Humboldt would be consulted about each State of the Union message. He was going to be the Goethe of the new government and build Weimar in Washington. (pp. 2527)

Humboldt thinks that Stevenson can help overcome the marginality of poets. If he is at the heart of the political system then Citrine, Humboldt, Huggins and all other intellectuals are there in. Stevenson reads his poems, carries his ballads in his electoral campaign. He is the representative of culture in politics and materialism. Humboldt and Kathleen left the village because they believed that Stevenson is about to create a democracy built on culture, philosophy, poetry and intellectuals. He is "Aristotle's great-souled man," and in his administration members 
quote Yeats and Joyce; they know Thucydides, and Humboldt himself would be the Goethe of his government. However, "Stevenson's defeat means a winning of American materialism and vulgarity over real culture to Humboldt (Rho, 1999, p. 111). His lunacy and over consciousness become the wisdom that would save him from the authority of crowd and low culture.

Eugene Henderson and Artur Sammler ascribe a moral and philosophical touch on their peculiar sense of madness. In a Derridian tone, they reject the rationality and the utilitarianism of the Western culture, the hegemony of the logocentric thinking, and seek to foreground a spiritual peace in their lives through Henderson's mythical journey to Africa "Who-Who was I? A millionaire wanderer and wayfarer. A brutal and violent man driven into the world. A man who fled his own country, settled by his forefathers. A fellow whose heart said, I want, I want. Who played the violin in despair, seeking the voice of angels" (Bellow, 1959, p. 67), and Sammler's memories and recollections. Overtoning a deconstructive mood, Henderson strives to achieve morality through being a mad intellect, which Lily, his second wife, reassures asserting "[...] one has to live not for evil but for good, not death but life, not illusion but reality" (p. 18). Lily's and Henderson's struggle against the deconstructive forces of society become their priority. Reality, life and good can be achieved only through their escaping the material life of New York, the lights of the cosmopolitan city, and the trivialities of masses that are lusting after worldly desires. In his Postmodern Ethic (1993), Zygmunt Bauman indicates that "Moral issues cannot be 'resolved,' nor the moral life of humanity guaranteed, by the calculating and legislative efforts of reason. Morality is not safe in the hands of reason [...] Reason cannot help the moral self without depriving the self of what makes the self-moral" (p. 195). Symmetrically, Henderson proposes that the calculations of reason and the rationality of science do not guarantee morality nor do they assure humanism; morality is in danger in the context of capitalism and materialism. In America, business and money replaced culture and intellectual thinking, and that is historically proven, Henderson admits. Books on how to achieve money are preferred to those of great thinkers. Henderson's over consciousness about this cultural and moral decay in America pushes him to escape, inspite of his wealth and social position "I am rich. From my old man I inherited three million dollars after taxes [...] Next order of business: I am a graduate of an Ivy League university" (Bellow, 1959, p. 7).

Sammler perceives madness as survival and critical consciousness about the twentieth century war atrocities and the decline of civility. He equates it with sainthood and wisdom "At the present level of the human evolution propositions were held by choices which were narrowed down to sainthood and madness. We are mad unless we are saintly, saintly only as we soar above madness" (Bellow, 1970, p. 87). It is the wisdom that comes by the end of the day, the end of an age and the end of a civilization. In his illuminations (1997), Walter Benjamin points out that "as Hegel put it, only when it is dark does the owl of Minerva begin its flight. Only in extinction is the collector comprehended" (p. 67). Sammler is the metaphorical representation of the owl Minerva, as he emerges as a culture collector and civilization gatherer at a time of crisis of culture and humanism in America, or what Bellow thinks as the late age of capitalism. "Sammler spends most of his daytime in the New York public library collecting and recording the culture of the masses in America, and thinking of the possibility of transplanting European Enlightenment to the New World, all the while watching the various social evils and vulgar lives of the masses on the street" (Rho, 1999, p. 58). However, his experience leads him to frustration and despair. He discovers that both the European and the American culture have been morally and ethically degenerating starting from the early twentieth century. Bellow himself experiences this frustration with regards to the modern American culture confessing in an interview with Robert Boyers that "Occasionally I worry about what's happening to culture in the United States, but on other days I think there is no culture in the United States, and there's no point in worrying about it" (p. 6). By culture, Bellow means the European classical culture, the Enlightenment, the eighteenth and the nineteenth century moral and ethical values.

Sammler becomes a historical relic and an exemplar of consciousness and wisdom. He juxtaposes religion as a form of spiritual release and madness as a pure moral and intellectual insight. Bellow writes in the novel, "Mr. Sammler had a symbolic character. He, personally, was a symbol. His friends and family had made him a judge and a priest. And of what was he a symbol?" (p. 91). The answer would be that he becomes a symbol of civility and wisdom in a society where low culture and masses dominate the scene. Again, Bellow points out that "the whole nation, all of civilized society, perhaps, [were] seeking the blameless state of madness. The privileged, the almost aristocratic state of madness" (p. 85). He agrees with Adorno and Horkheimer in their Dialectic of Enlightenment (1997) that "twentieth century neobarbarism was the direct heir of the eighteenth-century Enlightenment," which is "why enlightenment had succumbed to "self-destruction"” (pp. 146, 157). According to them man has entered into a new kind of barbarism and has lost his humanistic traits, and this can be seen in the atrocities of the two world wars, anti-Semitism, the Holocaust, the Cold War and fascism. Adorno and Horkheimer continue:

The Enlightenment has always aimed at liberating men from fear and establishing their sovereignty. Yet the 
fully enlightened earth radiates disaster triumphant. The program of the Enlightenment was the disenchantment of the world; the dissolution of myths and the substitution of knowledge for fancy. (p. 3)

Bellow maintains that the Enlightenment has always meant happiness, morality, freedom, justice to Kant, beauty and essence to Fichte, passion to Hume and Baudelaire, the absolute unity of faith and reason, object and subject, to Hegel, self-autonomy and free will to Nietzsche, science and value to Weber, progress, newness and dynamism to Habermas, humanism to Bauman, whose essence had already been gathered into its focal point in the Kantian moral philosophy. However, satirically it takes a wrong turn, and Sammler provides a good example of being a victim of the Enlightenment. His entire family was killed by the Nazi regime except for his daughter, Shula. He escaped from a totalitarian Europe dominated by the power of one man to a democratic America controlled by every man; he had to spend all the summer in a cemetery to save his life, like a dead man; he was wounded and blinded in war; he and Shula suffered from trauma after that; he was betrayed by most of his Polish friends when he fought for them. "He is a witness to the consequences of the Enlightenment, and deeply involved in it, and realizes that the history of the Enlightenment is no better than a series of killings" (p. 62). Privileged of being a man of high culture, Sammler becomes the symbol of deconstructing the symbols of low culture and mass society.

Herzog writes a new discourse that challenges the authority of existing discourses, and ends up becoming a mad intellect. Humboldt and Citrine begin where Herzog ends up, and finish seeking to rewrite the lost manuscript. Sammler, Corde and Henderson take Humboldt's and Citrine's project to reassure the wisdom of the intellect and their high consciousness about the age. All of them share one common point which is deconstructing the amorality and the animalistic features of the modern age, the low culture of masses and the decline of civility. The effect of this is to awaken the awareness of the scrupulous accordance of these protagonists, in their circular movement from madness to wisdom, with Foucault's structures of thought and Derrida's deconstruction to the grand-narratives of metaphysics. Here again, Bellow is suggesting that madness is a moment of peace, of erasing and rewriting new and different systems of thought, of legislating for more unbroken moral norms. Bellow deplores the theme of madness, and assumes that it is the absent truth of modern morality. The novelist, on this view, uses what modernity rejects, madness, to argue for what it adopts, humanism. This strategic method of argumentation might prove paradoxical in the sense that it embodies those strategies and methods that are typical of poststructuralist practice. However, this gesture reflects the novelist's early awareness of modernity's consciousness of time and its need of perpetual renewal, which Walter Benjamin explains with the innovative present in the continuum of history. The issue, as I shall demonstrate in the forthcoming chapters, is whether Bellow subverts the ancient and the modern norms, or he touches the overlap between modernity and "postmodernity" assuming, like Habermas, that the latter further enlightens the former. If the second thesis proves right, then this statement functions as not only another argument for the novelist's subversion, but also of his being modernist par excellence.

Bellow develops a theory of madness in his writings which is interchangeable with subversion, deconstruction and morality. In his lately published book It All Adds Up: from the Dim Past to the Uncertain Future (1995), he acknowledges this fact assuming that man's intellectual career is bound to a series of ruptures in the understanding of art and life. He Maintains:

When a writer says "my time is up," it's highly probable that he doesn't really mean it. What most saddens him is that his mistakes are indelibly recorded in what he once wrote. If I had it to do again I could do it so much better, he says, and he longs to correct himself publicly and to revise and retract. Some of my friends have been deeply skeptical about adult education. Prevailing opinion has been that it is no use to attempt in middle age what should have been done in the years of maximum receptivity. But some of us are stubborn learners, and my sixties and my seventies proved to be enlightening decades. I learned many things that I should have known earlier.

The bitterness of my dissatisfaction in rereading some of these pieces is due to basic revision, radical changes in my point of view. I can see now where I went wrong. The "road not taken" was taken, taken a hundred times. By now I have gone many miles toward the promise of sleep, but I reach my destination blindingly wide awake. My state therefore is something like a state of insomniac illumination. I failed to understand the things I wrote, the books I read, the lessons I was taught, but I find that I am a most persistent self-educator, that I long for correction. Very possibly I have not achieved my goals, but it gives great satisfaction nonetheless to have rid oneself of tenacious old errors. To enter an era of improved errors. (pp. xii-xiii)

Expressions like "mistakes $[\ldots]$ to correct myself $[\ldots]$ revise $[\ldots]$ skeptical $[\ldots]$ stubborn learners, enlightening $[\ldots]$ radical changes $[\ldots]$ where I went wrong $[\ldots]$ I long for correction $[\ldots]$ era of improved errors" overtone a scrupulous symmetry between Bellow's madness and Derrida's theory of deconstruction. Both develop a theory 
rests on the assumption that any meaning is always under a perpetual erasure, and that there is no final interpretation to the text. The novelist strengthens this parallelism in his 'Nobel Prize Lecture' (1976) admitting that he is still a student who is learning from Joseph Conrad, the Oriental style, Hemingway, Kafka, D. H. Lawrence, Moliere, Racine, Dickens, Balzac, the death of the author, the politics of totalitarianism, modern ethics (pp. 88-97). Bellow announces that subversion, madness and morality are the features that govern his reflections on deconstruction, and this is to be understood in line with self-correction, wisdom and morality, a gesture that places him in the Enlightenment tradition in Habermas's sense.

\section{Conclusion}

The discussion in this paper has focused on investigating the way the Enlightenment moral and ethical ideals influenced Bellow's protagonists and deepened their over consciousness about the rupture between intellectuals and masses in modern American cultural scene. It has analyzed the extent to which the Enlightenment thought has shaped the novelist's view of morality, humanism, happiness, man, art and life in general. Therefore, it has developed the thesis that Bellow's moral theory stems from the fundamental features of the Enlightenment's morality namely man's moral worth, human welfare, reason, faith, Man, God, happiness, madness, wisdom, peace etc. The researcher has purported concurrently to show how these values and ethics penetrated into the minds of Bellow's protagonists and deepened their consciousness about the marginalization of intellectuals and the centralization of low culture and mass society in twentieth century America. Bellow maintains that his heroes are wise intellectuals, though regarded mad beggars and poor strangers; and their over consciousness about their tragic fate in modern capitalistic and democratic America summons the deconstruction of these norms.

\section{References}

Atlas, J. (1977). Delmore Schwartz: The Life of an American Poet. New York: Farrar, Straus \& Giroux.

Bauman, Z. (1993). Postmodern Ethics. Malden: Blackwell Publishing.

Bellow, S. (1944). Dangling Man. New York: Vanguard Press,

Bellow, S. (1947). The Victim. New York: Vanguard Press.

Bellow, S. (1956). Seize the Day. New York: Vanguard Press.

Bellow, S. (1959). Henderson the Rain King. New York: Viking Press. https://doi.org/10.2307/3848167

Bellow, S. (1964). Herzog. New York: Viking Press.

Bellow, S. (1970). Mr. Sammler's Planet. New York: Viking Press.

Bellow, S. (1975). Humboldt's Gift. New York: Viking Press.

Bellow, S. (1976). To Jerusalem and Back: A Personal Account. New York: Viking Press.

Bellow, S. (1982). The Dean's December. New York: Vanguard Press.

Bellow, S. (1995). It All Adds Up: from the Dim Past to the Uncertain Career. New York: Penguin.

Bellow, S. (2001). Ravelstein. New York: Penguin.

Benjamin, W. (1997). Eduard Fuchs: Collector and Historian. In A. Andrew \& G. Eike (Eds.), The Essential Frankfurt School Reader. New York: Continuum.

Clayton, J. J. (1979). Saul Bellow in Defense of Man. Bloomington and London: Indiana University Press.

Derrida, J. (1972). Margins of Philosophy (Trans. By Alan Bass). Chicago: University of Chicago Press, 1982. Originally published as Marges de la philosophie. Paris: Editions de Minuit.

Derrida, J. (1976). Of Grammatology (Translated by Gayatri Chakravorty Spivak). London: The Johns Hopkins University Press.

Donnelly, T. (2012). Vogue Diagnoses: The Functions of Madness in Twentieth-Century American Literature. Oregon: University of Oregon.

Foucault, M. (1965). Madness and Civilization: A History of Insanity in the Age of Reason. New York: Pantheon.

Foucault, M. (1973). The Archaeology of Knowledge (Trans. Alan Sheridan). New York: Vintage.

Fuchs, D. (1984). Saul Bellow: Vision and Revision. New York: Duke University Press.

Glickman, S. (1989). The World as Will and Idea. In L. Cornine \& L. H. Goldman (Eds.), Saul Bellow in the 1980's: A Collection of Critical Essays. Eastlansing: Michigan State University Press.

Goldman, L. H. (1983). Saul Bellow's Moral Vision: A Critical Study of the Jewish Experience. New York: 
Irvington.

Goldman, L. H. (1986). Saul Bellow and the Philosophy of Judaism. In G. L. Cornine \& L. H. Goldman (Eds.), Saul Bellow in the Eighties: A Collection of Critical Essays. Eastlansing: Michigan State University Press.

Hegel, G. W. F. (1977). Phenomenology of Spirit (Translated by A. V. Miller). Oxford: Oxford University Press.

Hofstadter, R. (1966). Anti-intellectualism in American Life. New York: Alfred A. Knopf.

Horkheimer, M., \& Theodor, W. (1997). Dialectic of Enlightenment (Trans. John Cumming). New York: Continuum.

Hume, D. (1978). Enquiries Concerning Human Understanding and the Principles of Morals. Oxford: Clarenden Press.

Johnson, D. (1982). Saul Bellow as Reformer. In Terrorists and Novelists. New York: Alfred A. Knopf.

Kant, I. (1965). Religion within the Boundaries of Mere Reason (Trans. Norman Kemp Smith). New York: St. Martin's Press.

Kant, I. (1970). An Answer to the Question: What is Enlightenment? In H. B. Nisbet (Trans.), Political Writings. Cambridge: Cambridge University Press.

Lasch, C. (1969). The Agony of the American Left. New York: Alfred A Knopf.

Lasch, C. (1996). The Revolt of the Elites and the Betrayal of Democracy. New York: W. W. Norton.

Locke, J. (2002). John Locke: Writings on Religion (edited by Victor Nuovo). Oxford: Oxford University Press.

McCarthy, T. (1987). Introduction. In F. G. Lawrence (Trans.), The Philosophical Discourse of Modernity. Jürgen Habermas. Massachusetts: The MIT Press Cambridge.

Newman, J. (1989). Bellow's Sixth Sense: The Sense of History. In G. L. Cornine \& L. H. Goldman (Eds.), Saul Bellow in the Eighties: A Collection of Critical Essays. Eastlansing: Michigan State University Press.

Rho, H. (1999). Alienation of Intellectuals in Saul Bellow's Later Novels. New York: University of New York.

Schwartz, D. (1970). The Isolation of Modem Poetry. In D. A. Dike \& D. H. Zucker (Eds.), Selected Essays of Delmore Schwartz. Chicago: University of Chicago Press.

Siegel, B. (1978). Artists and Opportunists in Saul Bellow's Humboldt's Gift. Contemporary Literature, 19(2), 143-164. https://doi.org/10.2307/1207952

\section{Copyrights}

Copyright for this article is retained by the author, with first publication rights granted to the journal.

This is an open-access article distributed under the terms and conditions of the Creative Commons Attribution license (http://creativecommons.org/licenses/by/4.0/). 